\title{
The robustness of land equivalent ratio as a measure of yield advantage of multi-crop systems over monocultures
}

\author{
Debal Deb $^{1, *}$ (D) and Sreejata Dutta ${ }^{2}$ (D) \\ ${ }^{1}$ Centre for Interdisciplinary Studies, Barrackpore, India, and ${ }^{2}$ Department of Biostatistics \& Data Science, University of Kansas \\ Medical Center, Kansas City, Kansas, USA \\ ${ }^{*}$ Corresponding author. Email: debdebal@gmail.com
}

(Received 26 November 2021; Revised 29 December 2021; Accepted 29 December 2021)

\begin{abstract}
Land equivalent ratio (LER) is a most widely used indicator of yield advantage of multi-crop farms over solecrop farms, and usually measured using crop biomass yield per unit area. Most often, crop yields are compared between both systems using the same area. In this paper, we demonstrate that although the yield per unit area and the yield per plant are widely different, LER remains invariant. As a corollary, area time equivalent ratio and land use efficiency, derived from LER, also remain unchanged when using the two different measures of crop yields. We recommend that when the estimation of the exact land area is difficult due to complex crop planting designs, yield per plant estimate is much easier and equally valid for estimation of LER and its derivative indices.
\end{abstract}

Key words: land equivalent ratio; land use efficiency; monoculture; multiple cropping; yield advantage

\section{Introduction}

There is a general consensus that multiple cropping systems have superior yield potential over monocultures in agriculture and forestry (Gliessman, 2015; Huang et al., 2015; C.L.C. Liu et al., 2018; Maitra et al., 2021). However, experimental evidence of crop productivity enhancement in multi-crop (MC) systems has predominantly been confined to intercrops of no more than two species, compared to monocultures (e.g., Hamzei \& Seyedi, 2015; Morales-Rosales \& Franco-Mora, 2009; Raza et al., 2019; Runkulatile et al., 1998; and the references in Maitra et al., 2021; Table 1). Evidence from combinations of three crops is scarce (Andersen et al., 2007; Dapaah et al., 2003). The first experimental evidence of yield comparisons between $\mathrm{MC}$ farm plots with seven crop species and sole-crop (SC) plots of the same crop species, appeared in Deb (2021), revealed different degrees of efficiency of yield in different planting designs.

Deb's (2021) study measured the yield advantage of MC plots over SC plots by the land equivalent ratio (LER) based on edible biomass yield per plant, although it is usually estimated by measuring yield per unit of land area under crop cover (Khanal et al., 2021; Mead \& Willey, 1980; Weigelt \& Jolliffe, 2003). Here, we use both per plant $\left(Y_{i r}[p]\right)$ and per unit area $\left(Y_{i r}[a]\right)$ yields of the data from Deb (2021) to examine the sensitivity of LER with scaled units of measurement. In addition, we attempt to examine two more indices of yield advantages of MC farms planted to seven crops.

\footnotetext{
(c) The Author(s), 2022. Published by Cambridge University Press. This is an Open Access article, distributed under the terms of the Creative Commons Attribution licence (http://creativecommons.org/licenses/by/4.0), which permits unrestricted re-use, distribution and reproduction, provided the original article is properly cited.
} 


\section{Methods and materials}

\subsection{Study sites}

A total of eight farms in the State of Odisha, India, were selected for our experiments, whose details are given in Deb (2021). All these eight farms are owned by indigenous farmers, who traditionally grow 6-12 crop species on their farms every season. We chose seven crop species $(S=7)$ most commonly cultivated in the region, with zero synthetic agrochemical input. In addition to the seven species chosen for this experiment, a legume cover crop was planted on the farm margins. The yield of legumes was not included in this study, focusing instead on the seven different crops in each farm, compared to an SC plot of each of these seven species, separately grown. In this study, each replication of the eight farms includes three MC plots and seven SC plots.

\subsection{Crop planting designs}

As replacement designs are not practiced in real farms, and because replacement designs alter the individual crop densities, we chose to plant each crop species in equal proportions in all MC plots.

\subsubsection{SC plot design}

Two species of fruit crops (okra Abelmoschus esculentum and brinjal Solanum nigricum), three cereal crops (rice Oryza sativa ssp. indica, little millet Panicum sumatrense, and finger millet Eleusine coracana), and two leaf crops (red amaranth Amaranthus cruentus and green amaranth Amaranthus viridis) were planted in separate SC plots. The same cropping design was replicated in all the eight farms.

The SC plots were of the same size, and the crop plants were planted at a uniform spacing, with a planting density of $6.25 \mathrm{~m}^{-2}$ for brinjal saplings $(40 \mathrm{~cm} \times 40 \mathrm{~cm})$, and $16 \mathrm{~m}^{-2}$ for all other crops $(25 \mathrm{~cm} \times 25 \mathrm{~cm})$.

\subsubsection{MC plot designs}

A total of seven crop species were chosen for the MC farms. The crop species chosen for growing in the MC plots are: brinjal (BR), okra (OK), green amaranth (A1), red amaranth (A2), finger millet (FM), little millet (LM), and rice (RC).

In each farm, three designs (designated $\mathrm{A}, \mathrm{B}$, and $\mathrm{C}$ ) of $\mathrm{MC}$ plots, composed of $21 \times 21$ cells, were established (Figure 1). Crop plants in Design A were arranged in a row intercropping system, planted to all the seven species arranged in successive rows, repeated three times over. Design B is nonrandom mixed cropping, where seven crop species were planted in a fixed order, with each cell diagonally matching the species in the previous row and column. Thus, each row and each column differed in crop combination, although the order remained the same, repeated three times over. Design $\mathrm{C}$ was also nonrandom mixed cropping, albeit with a different arrangement of crop species. Like that of Design B, diagonal cells repeated each crop, matching the previous row and column, repeating the arrangement three times over in both dimensions.

\subsection{Crop area estimation}

In all the plots, the spacing on each side of a crop is $40 \mathrm{~cm}$ for BR, and $25 \mathrm{~cm}$ for all other crops. Any crop sitting next to BR must be $40 \mathrm{~cm}$ apart; so for all non-BR species, the spacing of $25 \mathrm{~cm}$ is subsumed in the 40-cm spacing for BR.

\subsubsection{SC plots}

Each SC plot consisted of 98 crop plants, sown in 14 rows and 7 columns. Adding a space of $40 \mathrm{~cm}$ (for $\mathrm{BR}$ ) or $25 \mathrm{~cm}$ (for all other crops) on the outer margin, the area under brinjal was estimated as 


\section{DESIGN A}

$\begin{array}{llllllllllllllllll} & 1 & 2 & 3 & 4 & 5 & 6 & 7 & 8 & \ldots & 13 & 14 & 15 & \ldots & 20 & 21 \\ 1 & \text { BR } & \text { OK } & \text { FM } & \text { RC } & \text { A1 } & \text { LM } & \text { A2 } & \text { BR } & \ldots & \text { LM } & \text { A2 } & \text { BR } & \ldots & \text { LM } & \text { A2 } \\ 2 & \text { BR } & \text { OK } & \text { FM } & \text { RC } & \text { A1 } & \text { LM } & \text { A2 } & \text { BR } & . . & \text { LM } & \text { A2 } & \text { BR } & . . & \text { LM } & \text { A2 } \\ 3 & \text { BR } & \text { OK } & \text { FM } & \text { RC } & \text { A1 } & \text { LM } & \text { A2 } & \text { BR } & . . & \text { LM } & \text { A2 } & \text { BR } & . . & \text { LM } & \text { A2 } \\ 4 & \text { BR } & \text { OK } & \text { FM } & \text { RC } & \text { A1 } & \text { LM } & \text { A2 } & \text { BR } & . . & \text { LM } & \text { A2 } & \text { BR } & . . & \text { LM } & \text { A2 } \\ 5 & \text { BR } & \text { OK } & \text { FM } & \text { RC } & \text { A1 } & \text { LM } & \text { A2 } & \text { BR } & . . & \text { LM } & \text { A2 } & \text { BR } & . . & \text { LM } & \text { A2 } \\ 6 & \text { BR } & \text { OK } & \text { FM } & \text { RC } & \text { A1 } & \text { LM } & \text { A2 } & \text { BR } & . . & \text { LM } & \text { A2 } & \text { BR } & . . & \text { LM } & \text { A2 } \\ 7 & \text { BR } & \text { OK } & \text { FM } & \text { RC } & \text { A1 } & \text { LM } & \text { A2 } & \text { BR } & . . & \text { LM } & \text { A2 } & \text { BR } & . . & \text { LM } & \text { A2 } \\ 8 & \text { BR } & \text { OK } & \text { FM } & \text { RC } & \text { A1 } & \text { LM } & \text { A2 } & \text { BR } & . . & \text { LM } & \text { A2 } & \text { BR } & . . & \text { LM } & \text { A2 } \\ \ldots & \ldots & \ldots & \ldots & \ldots & \ldots & \ldots & \ldots & \ldots & \ldots & \ldots & \ldots & \ldots & \ldots & \ldots & \ldots \\ 21 & \text { BR } & \text { OK } & \text { FM } & \text { RC } & \text { A1 } & \text { LM } & \text { A2 } & \text { BR } & & \text { LM } & \text { A2 } & \text { BR } & & \text { LM } & \text { A2 }\end{array}$

\section{DESIGN B}

$\begin{array}{llllllllllllllllll} & 1 & 2 & 3 & 4 & 5 & 6 & 7 & 8 & \ldots & 13 & 14 & 15 & \ldots & 20 & 21 \\ 1 & \text { BR } & \text { OK } & \text { FM } & \text { RC } & \text { A1 } & \text { LM } & \text { A2 } & \text { BR } & \ldots & \text { LM } & \text { A2 } & \text { BR } & \ldots & \text { LM } & \text { A2 } \\ 2 & \text { OK } & \text { FM } & \text { RC } & \text { A1 } & \text { LM } & \text { A2 } & \text { BR } & \text { OK } & . . & \text { A2 } & \text { BR } & \text { OK } & . . & \text { A2 } & \text { BR } \\ 3 & \text { FM } & \text { RC } & \text { A1 } & \text { LM } & \text { A2 } & \text { BR } & \text { OK } & \text { FM } & . . & \text { BR } & \text { OK } & \text { FM } & . . & \text { BR } & \text { OK } \\ 4 & \text { RC } & \text { A1 } & \text { LM } & \text { A2 } & \text { BR } & \text { OK } & \text { FM } & \text { RC } & . . & \text { OK } & \text { FM } & \text { RC } & . . & \text { OK } & \text { FM } \\ 5 & \text { A1 } & \text { LM } & \text { A2 } & \text { BR } & \text { OK } & \text { FM } & \text { RC } & \text { A1 } & . . & \text { FM } & \text { RC } & \text { A1 } & . . & \text { FM } & \text { RC } \\ 6 & \text { LM } & \text { A2 } & \text { BR } & \text { OK } & \text { FM } & \text { RC } & \text { A1 } & \text { LM } & . . & \text { RC } & \text { A1 } & \text { LM } & . . & \text { RC } & \text { A1 } \\ 7 & \text { A2 } & \text { BR } & \text { OK } & \text { FM } & \text { RC } & \text { A1 } & \text { LM } & \text { A2 } & \ldots & \text { A1 } & \text { LM } & \text { A2 } & . . & \text { A1 } & \text { LM } \\ 8 & \text { BR } & \text { OK } & \text { FM } & \text { RC } & \text { A1 } & \text { LM } & \text { A2 } & \text { BR } & . . & \text { LM } & \text { A2 } & \text { BR } & . . & \text { LM } & \text { A2 } \\ \ldots & \ldots & \ldots & \ldots & \ldots & \ldots & \ldots & \ldots & \ldots & \ldots & \ldots & \ldots & \ldots & . . & \ldots & \ldots \\ 21 & \text { A2 } & \text { BR } & \text { OK } & \text { FM } & \text { RC } & \text { A1 } & \text { LM } & \text { A2 } & \ldots & \text { OK } & \text { FM } & \text { A2 } & \ldots & \text { OK } & \text { FM }\end{array}$

DESIGN C

$\begin{array}{lllllllllllllllll} & 1 & 2 & 3 & 4 & 5 & 6 & 7 & 8 & \ldots & 13 & 14 & 15 & \ldots & 20 & 21 \\ 1 & \text { BR } & \text { FM } & \text { A1 } & \text { RC } & \text { LM } & \text { A2 } & \text { OK } & \text { BR } & \ldots & \text { A2 } & \text { OK } & \text { BR } & \ldots & \text { A2 } & \text { OK } \\ 2 & \text { FM } & \text { A1 } & \text { RC } & \text { LM } & \text { A2 } & \text { OK } & \text { BR } & \text { FM } & . . & \text { OK } & \text { BR } & \text { FM } & . . & \text { OK } & \text { BR } \\ 3 & \text { A1 } & \text { RC } & \text { LM } & \text { A2 } & \text { OK } & \text { BR } & \text { FM } & \text { A1 } & \ldots & \text { BR } & \text { FM } & \text { A1 } & . . & \text { BR } & \text { FM } \\ 4 & \text { RC } & \text { LM } & \text { A2 } & \text { OK } & \text { BR } & \text { FM } & \text { A1 } & \text { RC } & . . & \text { FM } & \text { A1 } & \text { RC } & . . & \text { FM } & \text { A1 } \\ 5 & \text { LM } & \text { A2 } & \text { OK } & \text { BR } & \text { FM } & \text { A1 } & \text { RC } & \text { LM } & . . & \text { A1 } & \text { RC } & \text { LM } & . . & \text { A1 } & \text { RC } \\ 6 & \text { A2 } & \text { OK } & \text { BR } & \text { FM } & \text { A1 } & \text { RC } & \text { LM } & \text { A2 } & . . & \text { RC } & \text { LM } & \text { A2 } & . . & \text { RC } & \text { LM } \\ 7 & \text { OK } & \text { BR } & \text { FM } & \text { A1 } & \text { RC } & \text { LM } & \text { A2 } & \text { OK } & . . & \text { LM } & \text { A2 } & \text { OK } & . . & \text { LM } & \text { A2 } \\ 8 & \text { BR } & \text { FM } & \text { A1 } & \text { RC } & \text { LM } & \text { A2 } & \text { OK } & \text { BR } & . . & \text { A2 } & \text { OK } & \text { BR } & . . & \text { A2 } & \text { OK } \\ \ldots & \ldots & \ldots & \ldots & \ldots & \ldots & \ldots & \ldots & \ldots & \ldots & \ldots & \ldots & \ldots & \ldots & \ldots & \ldots \\ 21 & \text { OK } & \text { BR } & \text { FM } & \text { A1 } & \text { RC } & \text { LM } & \text { A2 } & \text { OK } & \ldots & \text { LM } & \text { A2 } & \text { OK } & \ldots & \text { LM } & \text { A2 }\end{array}$

Figure 1. The planting designs A, B, and C for seven crop species. The numbers in the first column denote respective row numbers, and the numbers in the top row denote respective column numbers.

Legends: A1: green amaranth; A2: red amaranth; BR: brinjal; FM: finger millet; LM: little millet; OK: okra; RC: rice. 


$$
A_{B R}=(8 \times 40 \mathrm{~cm}) \times(15 \times 40 \mathrm{~cm})=192,000 \mathrm{~cm}^{2}=19.2 \mathrm{~m}^{2},
$$

whereas that for each of the other six crops was estimated as

$$
A_{i \neq B R}=(8 \times 25 \mathrm{~cm}) \times(15 \times 25 \mathrm{~cm})=75,000 \mathrm{~cm}^{2}=7.5 \mathrm{~m}^{2} .
$$

\subsubsection{MC plots}

Because the number of plants and the density of each crop are the same in all MC plots, all the plot areas in Designs A, B, and C are identical. The general formula we used for calculating the land area $(A)$ in the MC plot design is

$$
A_{r-M C}=\sum_{i-1}^{7} A_{i}=G_{i}^{2}(\mathrm{R}+1)[\mathrm{X}+\mathrm{Y}]
$$

where $C_{i}$ is the number of columns in which crop $i$ is repeatedly planted in each row, and is uniformly 3 in our experiments, $R$ is the number of rows in each plot, which is uniformly 21 , and $G_{i}$ is the spacing between each pair of plants, with the following conditions:

$$
\begin{array}{ll}
G_{i}=40 \mathrm{~cm}, X=2 C_{i}, \text { and } Y=0, & \text { for } i=B R, \\
G_{i}=25 \mathrm{~cm}, X=0, \text { and } Y=1+C_{i}(S-1), & \text { for } i \neq B R,
\end{array}
$$

where $S(=6)$ is the number of non-BR species planted in each row. The derivation of equation (S4) is given in Supplementary Material S1.

The actual area (AA) of each replicate MC plot was calculated as:

$$
A A_{r-M C}=\sum_{i-1}^{7} A_{i r}\left(N_{i r} / C_{i} R\right)=\sum_{i-1}^{7} A_{i r} N_{i r} / 63,
$$

where $A_{i r}$ is the land area for the $i$ th crop in the replicate $r$, and $N_{i r}(\leq 63)$ is the number of surviving plants belonging to crop species $i$ in the replicate $r=1,2, \ldots, 8$.

\subsection{Quantification of crop yield}

The edible parts of each crop were harvested after maturity, and the quantity of the edible biomass harvested from each crop was separately weighed using a spring balance. The total crop harvest from each SC farm was weighed together, whereas the produce from the crops from each row and column from MC plots were separately weighed. As the fruits of brinjal and okra were harvested multiple times, the total weight of the fruits from each plant was estimated by successively adding their weights after each harvest (Deb, 2021).

\subsubsection{Yield per plant}

Considering the mortality of a few plants in different plots, we counted the number of surviving plants of each crop species in each farm plot, and estimated the per-plant productivity $\left(Y_{i r}[p]\right)$ of crop $i$ in the replicate plot $r$ as

$$
Y_{i r}[p]=P_{i r} / N_{i r}
$$

where $P_{i r}$ is the absolute yield of the $i$ th crop in replicate $r$ and $N_{i r}$ is the number of surviving plants belonging to crop species $i$ in the replicate plot $r$. 


\subsubsection{Yield per unit area}

Yield per unit area $\left(Y_{i r}[a]\right)$ for crop $i$ harvested from the replicate plot $r$ was calculated by the standard procedure of dividing the absolute yield per unit area by the proportionate area in each plot:

$$
Y_{i r}[a]=P_{i r} / A A_{i r}
$$

where $A A_{i r}$ is the AA of the $r$ th replicate plot under the $i$ th crop and $P_{i r}$ is the absolute yield of the $i$ th crop in replicate $r$.

To scale the yield of each SC plot at par with MC plots (with 63 plants), we calculated

$$
Y_{i r-S C}=63\left(P_{i r-S C} / N_{i r-S C}\right) \text {, }
$$

where $P_{i r}$ is the absolute yield of the $i$ th crop in the replicate plot $r$. The yield per unit area of each SP $i$ in the replicated SC plots was then calculated as

$$
Y_{i r-S C}[a]=Y_{i r-S C} / A_{r-M C}
$$

with $A_{r-M C}$ obtained from equation (S4). Equation (4b) thus enables a comparison between the yields of each crop from an equal area of SC and MC plots.

\subsection{Indices of relative yield performance}

\subsubsection{Land equivalent ratio}

Yield efficiency of MC with $S=7$ crop species, compared to SC systems, was measured by LER (Mead \& Willey, 1980):

$$
L E R=\sum_{i-1}^{7}\left(Y_{i M C} / Y_{i S C}\right),
$$

where $Y_{i M C}$ is the yield of the $i$ th crop in the MC system (see equations (2) and (3) and $Y_{i S C}$ is the yield of the same crop in SC plots. The total number of crop species planted to the poly-crop farm plots $\Sigma i=7$. An LER of $>1$ indicates that the amount of land required by the MC system is less than that of the SC farm to produce an equal yield. Conversely, an LER of $<1$ signifies more amount of land required for the MC farm to be as productive as the $\mathrm{SC}$ farm. Although LER is usually estimated using the yield of each crop per unit area, we made use of both $Y_{i r}[a]$ and $Y_{i r}[p]$ for each planting design.

\subsubsection{Area time equivalent ratio}

A more realistic comparison of the yield advantage of MC over SC considering the time duration of the component crops in the system, area time equivalent ratio (ATER; Aasim et al., 2008; Hiebsch \& McCollum, 1987), is calculated as

$$
\begin{gathered}
A T E R=\sum_{i-1}^{7} A T E R_{i}, \\
\operatorname{ATER}_{i}=\left(Y_{i M C} / Y_{i S C}\right)\left(T_{i} / T_{L}\right),
\end{gathered}
$$

where $T_{i}$ is the duration (in days) of the growth cycle of the $i$ th crop species and $T_{L}$ is the duration of the species with the longest growth cycle. In our experiments, $T_{L}=155$ days. 


\subsubsection{Land use efficiency}

The arithmetic average of LER and ATER is likely to give a more precise estimation of yield advantage than LER and ATER (Mason et al., 1986):

$$
L U E=\frac{(L E R+A T E R)}{2} .
$$

Originally put forward by Mason et al. (1986), equation (7) has been wrongly cited, and also corrupted by several authors. For instance, Yaseen et al. (2014) and Gitari et al. (2020) cited Mead and Willey (1980) as the progenitor of the formula, and also used a spurious formula for land use efficiency (LUE), which vitiated the results and interpretations of their experiments. Clearly, these authors and their peer reviewers had ignored to check up the cited works of Mason et al. (1986) and Mead and Willey (1980). Our present work intends to rectify these grave flaws.

\section{Results and discussion}

The data of edible biomass yield of each crop from all the SC and MC plots are given in (Deb, 2021). The area and edible biomass yield per unit of land area $(Y[\mathrm{a}])$ under each crop species from all plots are given in Supplementary Tables A1-A4. The data of edible biomass yield per plant $(Y[p])$ of all the crops are available in Table S1 of Deb (2021), and therefore not repeated here.

Figure 2 and Supplementary Tables A1-A3 show that the yield of each of the seven crops in MC farms is less than that of the same crops in SC plots. However, LER analyses reveal that the mean yields of the crops planted in mixed designs $\mathrm{B}$ and $\mathrm{C}$ are considerably greater than when the same crops are planted in either SC plots or in row intercropping (Design A), as discussed in detail in Deb (2021). The mean LER for the eight MC farms planted in Design B is 5.15, with a $95 \%$ confidence interval of $(4.6,5.7)$; the mean LER Design C is 5.67, with a $95 \%$ confidence interval of $(5.0,6.3)$.

Here, we focus our analysis to estimations of yield and yield advantage indicators, and highlight that although the values of $Y_{i r}[p]$ and $Y_{i r}[a]$ are widely different, the values of LER using both $Y_{i r}[p]$ and $Y_{i r}[a]$ are identical (Table 1). While corroborating and expanding upon the findings of a large number of previous studies of MC systems compared to SC systems (e.g., the references cited in the Introduction section), our findings demonstrate for the first time that the value of LER remains invariant for both biomass per plant and biomass per unit area estimations. In fact, when $A_{i}$ is identical in all the replicate plots $(r=1,2,3, \ldots, 8)$, and the number of crop plants $N_{i}$ in all the replicate plots is identical $\left(N_{i}=N_{i r}\right)$, $Y_{i}[a]$ and $Y_{i}[p]$ are mutually derivable:

$$
\begin{gathered}
Y_{i}[p]=\left(A_{i} / N_{i}\right) Y_{i}[a], \\
\text { or, } Y_{i}[a]=\frac{1}{\left(A_{i} / N_{i}\right)} Y_{i}[p] .
\end{gathered}
$$

Table 1. Land equivalent ratio (LER), area time equivalent ratio (ATER), and land use efficiency (LUE) of multi-crop farms with seven crop species, planted in three different designs.

\begin{tabular}{llllllll} 
& \multicolumn{3}{c}{ Mean yield per unit area estimate } & & \multicolumn{3}{c}{ Mean yield per plant estimate } \\
\cline { 2 - 3 } Planting design & LER & ATER & LUE & & LER & ATER & LUE \\
\hline A & 1.17 & 0.74 & 0.96 & & 1.17 & 0.74 & 0.96 \\
\hline B & 5.15 & 3.21 & 4.18 & & 5.15 & 3.21 & 4.18 \\
\hline C & 5.65 & 3.54 & 4.59 & & 5.65 & 3.54 & 4.59 \\
\hline
\end{tabular}




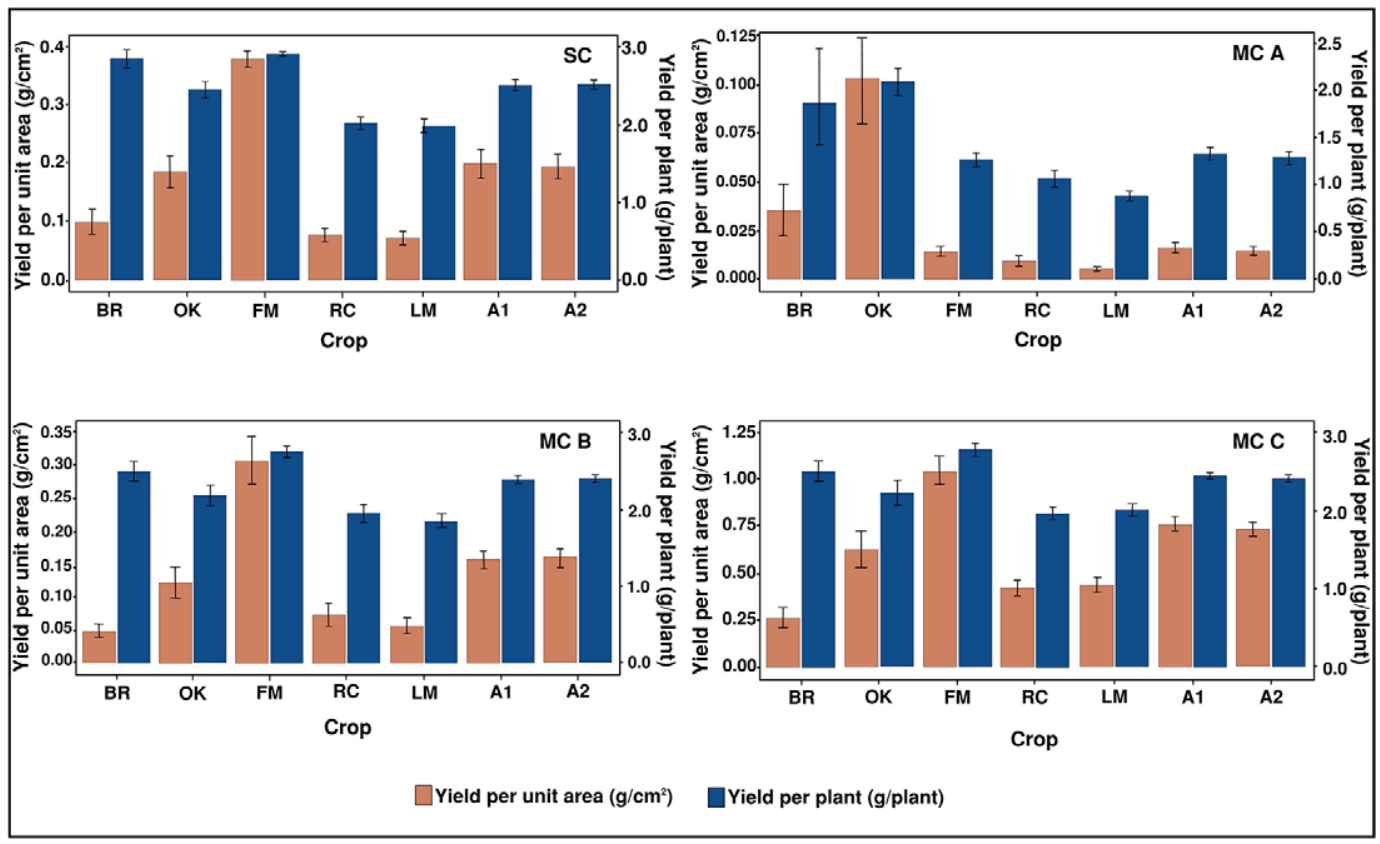

Figure 2. Mean yield of crops in sole-crop and multi-crop farm plots. Vertical bars show standard deviations.

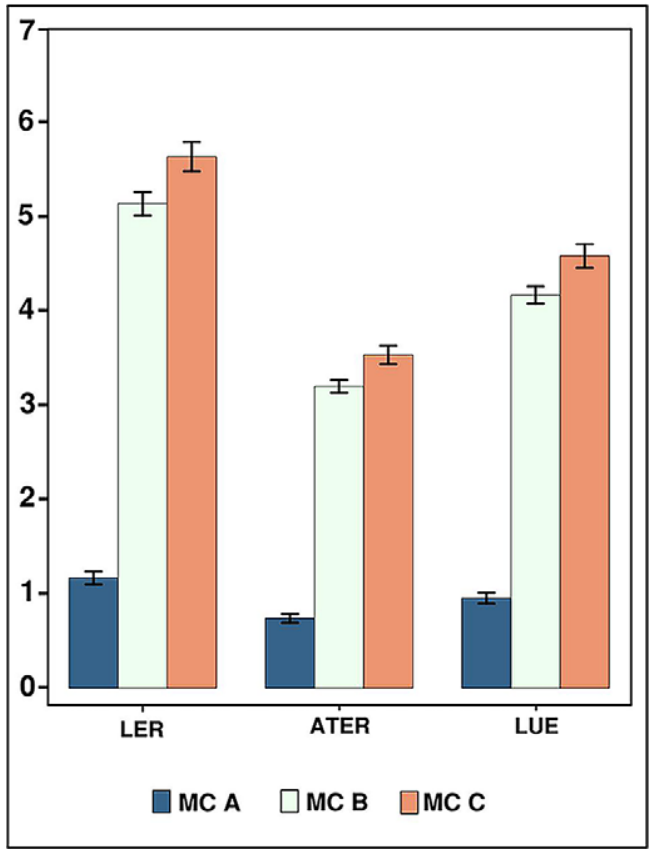

Figure 3. Mean LER, ATER, and LUE, invariant with $Y[p]$ and $Y[a]$ calculations of multi-crop plots with Designs $A$, B, and C. Vertical bars indicate standard deviations. 
We denote the area per plant $\left(A_{i} / N_{i}\right)$ as the determining constant in the estimation of yield, so long as the intra- and interspecific spacings are kept invariant across all planting designs. Table 1 shows that LER remains invariant when calculated using both $\mathrm{Y}[\mathrm{a}]$ and $\mathrm{Y}[\mathrm{p}]$. As a corollary, the values of ATER and LUE are also identical in both cases. Figure 3 illustrates the mean LER, ATER, and LUE for all three MC designs.

Because LER estimated using $Y_{i}[a]$ is no different from LER estimated using $Y_{i}[p]$, the value of ATER and that of LUE also remain invariant for both Y[a] and Y[p], as shown in Table 1 and Figure 3.

\section{Conclusion}

The primary results of this study are in conformity with previous, albeit limited, number of experimental productivity studies with mixed and polyculture systems, demonstrating that (a) overall crop yields of MC farms are decidedly superior to those of SC farms and (b) MC with row intercropping is scarcely more productive than monocultures (Deb, 2021). This study also demonstrates that LER is a robust indicator of yield advantages, as it remains invariant whether estimated in terms of land area or the number of plants. ATER and LUE, derived from LER, are also robust, and truthfully depict the yield advantage of MC systems over SC systems.

Estimation of exact land area under a crop species in the MC farm plots is often a rigorous exercise, especially with complex crop planting designs with variable spacings between crop plants. Moreover, there is some scope of confusion in estimation of area, as some authors prefer to calculate the total land area in the MC plot, instead of the "occupied area" (e.g., X. Liu et al., 2018). In real-life situations, where indigenous farmers often randomly sow the seeds of diverse crop species with variable intercrop spacings in their MC farms, estimation of the land area is a tedious exercise. In such cases of difficulty in measuring yield per unit area $\left(Y_{i r}[a]\right)$, yield per-plant $\left(Y_{i r}[p]\right)$ estimation is much easier. Thus, LER, ATER, and LUE may safely be calculated using $Y_{i r}[p]$, without compromising the exactitude of their values, as demonstrated in Table 1.

Acknowledgments. We are grateful to Sachin Panigrahi for computer entry and formatting of all data. All logistic support to the field experiments was provided by Mr. Debjeet Sarangi of Living Farms, Bhubaneswar, who left our world during the preparation of this manuscript.

Supplementary Materials. To view supplementary material for this article, please visit http://doi.org/10.1017/exp.2021.33.

Data availability statement. All data are freely available on request.

Funding statement. Neither this work nor the authors received any financial support from any source.

Conflicts of interest. The authors declare that there are no conflicts of interest.

\section{References}

Aasim, M., Umer, E. M., \& Karim, A. (2008). Yield and competition indices of intercropping cotton (Gossypium hirsutum L.) using different planting patterns. Tarim Bilimleri Dergisi: Journal of Agricultural Sciences, 14, 326-333.

Andersen, M. K., Hauggaard-Nielsen, H., Weiner, J., \& Jensen, E. S. (2007). Competitive dynamics in two- and threecomponent intercrops. Journal of Applied Ecology, 44, 545-551. https://doi.org/10.1111/j.1365-2664.2007.01289.x

Dapaah, H. K., Asafu-Agyei, J. N., Ennin, S. A., \& Yamoah, C. (2003). Yield stability of cassava, maize, soya bean and cowpea intercrops. Journal of Agricultural Science, 140, 73-82. https://doi.org/10.1017/S0021859602002770

Deb, D. (2021). Productive efficiency of traditional multiple cropping systems compared to monocultures of seven crop species: A benchmark study. Experimental Results, 2, e18. https://doi.org/10.1017/exp.2021.7

Gitari, H. I., Nyawade, S. O., Kamau, S., Karanja, N. N., Gachene, C. K. K., Raza, M. A., Maitra, S., \& Schulte-Geldermann, E. (2020). Revisiting intercropping indices with respect to potato-legume intercropping systems. Field Crops Research, 258, 107957. https://doi.org/10.1016/j.fcr.2020.107957

Gliessman, S. (2015). Agroecology. The ecology of sustainable food systems (3rd ed.). CRC Press.

Hamzei, J., \& Seyedi, M. (2015). Evaluation of the effects of intercropping systems on yield performance, land equivalent ratio, and weed control efficiency. Agricultural Research, 4, 202-207. https://doi.org/10.1007/s40003-015-0161-y 
Hiebsch, C. K., \& McCollum, R. E. (1987). Area- $\times$-time equivalency ratio: a method for evaluating the productivity of intercrops. Agronomy Journal, 79, 15-22. https://doi.org/10.2134/agronj1987.00021962007900010004x

Huang, C., Liu, Q., Heerink, N., Stomph, T., Li, B., Liu, R., Zhang, H., Wang, C., Li, X., Zhang, C., Van Der, W., \& Zhang, F. (2015). Economic performance and sustainability of a novel intercropping system on the North China Plain. PLoS One, 10, e0135518. https://doi.org/10.1371/journal.pone.0135518

Khanal, K., Stott, K. J., Armstrong, R., Nuttall, J. G., Henry, F., Christy, B. P., Mitchell, M., Riffkin, P. A., Wallace, A. J., McCaskill, M., Thayalakumaran, T., \& O'Leary, G. J. (2021). Intercropping-Evaluating the advantages to broadacre systems. Agriculture, 11, 453. https://doi.org/10.3390/agriculture11050453

Liu, C. L. C., Kuchma, O., \& Krutovsky, K. V. (2018). Mixed-species versus monocultures in plantation forestry: Development, benefits, ecosystem services and perspectives for the future. Global Ecology and Conservation, 15, e00419. https://doi.org/ 10.1016/j.gecco.2018.e00419

Liu, X., Rahman, T., Song, C., Yang, F., Su, B., Cui, L., Bu, W., \& Yang, W. (2018). Relationships among light distribution, radiation use efficiency and land equivalent ratio in maize-soybean strip intercropping. Field Crops Research, 224, 91-101.

Maitra, S., Hossain, A., Brestic, M., Skalicky, M., Ondrisik, P., Gitari, H., Brahmachari, K., Shankar, T., Bhadra, P., Palai, J. B., Jena, J., Bhattacharya, U., Duvvada, S. K., Lalichetti, S., \& Sairam, M. (2021). Intercropping-A low input agricultural strategy for food and environmental security. Agronomy, 11, 343. https://doi.org/10.3390/agronomy11020343

Mason, S. C., Leihner, D. E., \& Vorst, J. J. (1986). Cassava-cowpea and cassava-peanut intercropping. I. Yield and land use efficiency. Agronomy Journal, 78, 43-46. https://doi.org/10.2134/agronj1986.00021962007800010010x

Mead, R., \& Willey, R. W. (1980). The concept of a "land equivalent ratio" and advantages in yields from intercropping. Experimental Agriculture, 16, 217-228. https://doi.org/10.1017/S0014479700010978

Morales-Rosales, E. J., \& Franco-Mora, O. (2009). Biomass, yield and land equivalent ratio of Helianthus annus L. in sole crop and intercropped with Phaseolus vulgaris L. in high valleys of Mexico. Tropical and Subtropical Agroecosystems, 10, 431-439.

Raza, M. A., Khalid, M. H. B., Zhang, X., Feng, L. Y., Khan, I., Hassan, M. J., Ahmed, M., Ansar, M., Chen, Y. K., Fan, Y. F., Yang, F., \& Yang, W. (2019). Effect of planting patterns on yield, nutrient accumulation and distribution in maize and soybean under relay intercropping systems. Scientific Reports, 9, 4947. https://doi.org/10.1038/s41598-019-41364-1

Runkulatile, H., Homma, K., Horie, T., Kurusu, T., \& Inamura, T. (1998). Land equivalent ratio of groundnut-finger millet intercrops as affected by plant combination ratio, and nitrogen and water availability. Plant Production Science, 1, 39-46. https://doi.org/10.1626/pps.1.39

Weigelt, A., \& Jolliffe, P. (2003). Indices of plant competition. Journal of Ecology, 91, 707-720. https://doi.org/10.1046/j.13652745.2003.00805.x

Yaseen, M., Singh, M., \& Ram, D. (2014). Growth, yield and economics of vetiver (Vetiveria zizanioides L. Nash) under intercropping system. Industrial Crops and Products, 61, 417-421. https://doi.org/10.1016/j.indcrop.2014.07.033

Cite this article: Deb D, Dutta S (2022). The robustness of land equivalent ratio as a measure of yield advantage of multicrop systems over monocultures. Experimental Results, 3, e2, 1-13. https://doi.org/10.1017/exp.2021.33 


\section{Peer Reviews}

\section{Reviewing editor: Dr. Richard Erickson}

US Geological Survey, Upper Midwest Environmental Sciences Center, 2630 Fanta Reed Rd, La Crosse, Wisconsin, United States, 54603

This article has been accepted because it is deemed to be scientifically sound, has the correct controls, has appropriate methodology and is statistically valid, and has been sent for additional statistical evaluation and met required revisions.

doi:10.1017/exp.2021.33.pr1

Review 1: The Robustness of Land Equivalent Ratio as a Measure of Yield Advantage of MultiCrop Systems over Monocultures

Reviewer: Poyyamoli Gopalakrishnan

Date of review: 08 December 2021

(C) The Author(s), 2022. Published by Cambridge University Press. This is an Open Access article, distributed under the terms of the Creative Commons Attribution licence (http://creativecommons.org/licenses/by/4.0), which permits unrestricted re-use, distribution and reproduction, provided the original article is properly cited.

Conflict of interest statement. Reviewer declares none

Comments to the Author: It is an excellently designed study. Add a few more recent references and discuss them in the text.

\section{Score Card}

Presentation

Is the article written in clear and proper English? (30\%)

Is the data presented in the most useful manner? (40\%)

Does the paper cite relevant and related articles appropriately? (30\%)

Context

5.0

Does the title suitably represent the article? (25\%)

Does the abstract correctly embody the content of the article? (25\%)

Does the introduction give appropriate context? (25\%)

Is the objective of the experiment clearly defined? (25\%) 
Are the limitations of the experiment as well as the contributions of the experiment clearly outlined? (20\%) 
Review 2: The Robustness of Land Equivalent Ratio as a Measure of Yield Advantage of MultiCrop Systems over Monocultures

Reviewer: Dr. Sabyasachi Bhattacharya

Date of review: 24 December 2021

(C) The Author(s), 2022. Published by Cambridge University Press. This is an Open Access article, distributed under the terms of the Creative Commons Attribution licence (http://creativecommons.org/licenses/by/4.0), which permits unrestricted re-use, distribution and reproduction, provided the original article is properly cited.

Conflict of interest statement. Reviewer declares none.

Comments to the Author: I still have some comments on this article for a better representation of this research. The comments are furnished below:

1. The relation between $\mathrm{N} \_$ir and $\mathrm{N} \_\mathrm{i}$ (used in Eq. 8a, Eq. 8b) is not mentioned in the manuscript.

2. Is there any distinguishable factor that exists between ATER and LUE? Do they always give the same value?

3. I think the interpretation of Land use efficiency (LUE) should be more elaborative.

4. Is the greater value of the Land Equivalent Ratio (LER > 1) sufficient to prove its robustness? I do agree with the author that the evaluated values of LER are much greater than one, but as this is a research article, so statistical significance test is necessary.

5. In the manuscript, the authors should mention the range of the term ' $r$ ' when used in different expressions.

6. The comma (,) and colon (:) are wrongly placed throughout the entire manuscript. Some wrong spelling appeared, e.g., useboth (line 1, page 1), practised (line 5, page 2). I think the author should check the entire manuscript before submitting the revised version.

7. In the supporting document, $\mathrm{S}$ is missing just before Eq. S4, $\sum$ is also missing from Eq. S3

\section{Score Card}

Presentation

Is the article written in clear and proper English? (30\%)

Is the data presented in the most useful manner? (40\%)

Does the paper cite relevant and related articles appropriately? (30\%)

Context

Does the title suitably represent the article? (25\%)

Does the abstract correctly embody the content of the article? (25\%)

Does the introduction give appropriate context? (25\%)

Is the objective of the experiment clearly defined? (25\%) 
Are the limitations of the experiment as well as the contributions of the experiment clearly outlined? (20\%) 